\title{
In vitro and in vivo investigation of the genotoxic potential of waters from rivers under the influence of a petroleum refinery (São Paulo State - Brazil)
}

\author{
Raquel Vaz Hara, Maria Aparecida Marin-Morales* \\ UNESP - Institute of Biosciences, Department of Biology, Av 24-A, 1515, CEP 13506-900, Rio Claro, São Paulo, Brazil
}

\section{H I G H L I G H T S}

- Bioassays are important for evaluating environmental impacts of oil refinery.

- PAH presence in rivers can both threaten ecosystems and human health.

- A. cepa and CHO-K1 tests are suitable for checking pollutants from the oil refinery.

- Biological and stabilization pond treatment reduces toxicity of oil refinery effluent.

- Biological treatment associated with stabilization pond reduced effluent toxicity.

\section{A R T I C L E I N F O}

\section{Article history:}

Received 15 July 2016

Received in revised form

25 January 2017

Accepted 28 January 2017

Available online 31 January 2017

Handling Editor: Frederic Leusch

\section{Keywords:}

HPA

Allium cepa

CHO cell culture

Chromosomic aberrations

Micronucleus

Refinery effluent

\begin{abstract}
A B S T R A C T
In recent years concern about the chemical composition of wastewater generated by the oil refining industry has increased, even after its treatment. These wastewaters contain substances that can harm both the entire aquatic ecosystem and the health of any exposed organisms. The aim of this study was to evaluate the genotoxic and mutagenic potentials of the effluent generated by the largest Brazilian petroleum refinery, the effectiveness of the treatments used by the refinery, and whether its effluent can compromise the water quality of the river where it is discarded. Chromosomal aberration and micronucleus assays were performed in Allium cepa and micronucleus test in mammalian cell culture (CHOK1). The samples were collected in three sites at the refinery: one site on the Jaguari River and two sites on the Atibaia Rivers (upstream and downstream of the discharged effluent), under three different climatic conditions. Tests with A. cepa showed increased frequencies of chromosomal aberrations and micronuclei in meristematic cells for the effluent after physico-chemical treatment, but the samples after treatment biological and stabilization pond presented none of these abnormalities. It was observed that the induced damage in the meristematic cells was not observed in the $F_{1}$ cells of $A$. cepa roots. The micronucleus test performed with mammalian cell culture also indicated that the effluent, after physicochemical treatment, induced a significant increase in micronucleus frequencies. Plant and hamster cells exposed to the other samples collected inside the refinery and in the Jaguari and Atibaia Rivers did not present evidence of genotoxicity and mutagenicity in the tests performed. This study showed that the effluent treated carried out by the refinery (biological treatment followed by a stabilization pond) proved to be efficient for the removal of the toxic load still present after the physico-chemical treatment, since no change in the quality of the Atibaia River was observed. However, because this is an industry with a high production of effluent with toxic potential, its effluents must be constantly monitored, so that there is no compromise of the water quality of the receiving river.
\end{abstract}

(c) 2017 Elsevier Ltd. All rights reserved.

\footnotetext{
* Corresponding author.

E-mail address: mamm@rc.unesp.br (M.A. Marin-Morales).
}

\section{Introduction}

Petroleum is used worldwide as a primary source of energy and as a raw material for many products such as plastics, solvents, pharmaceuticals, cosmetics, fuel, synthetic rubber and others. 
Because of this intense application, the oil and its derivatives also constitute an important class of environmental contaminants (Mazzeo et al., 2011).

Oil refinery activities require a large amount of water, which results in the production of significant volumes of wastewater (Nwanyanwu and Abu, 2010). In order for the wastewater to be released into the environment, it must be subjected to specific physical, chemical and biological treatments that remove the high concentrations of pollutants, such as aliphatic and aromatic hydrocarbons, present in the effluent (Saien and Shahrezaei, 2012). However, aromatic hydrocarbons produced by the refineries are difficult to remove from the final effluent by conventional treatment systems, requiring a combination of additional techniques, such as treatment in stabilization ponds, before it is released into the environment (Almasi et al., 2014).

Water is the final destination of all pollution and, therefore, there is a great concern in ensuring its quality. In order to ensure the quality of water resources, it is appropriate to assess the possible sources of contamination and the types of pollutants that can be present in the aquatic environment, since many chemicals may compromise the health of their consumers (Rhind, 2009). Therefore, Kim et al. (2008) and Xiang et al. (2012) point out the need to identify, characterize and evaluate the presence and types of toxic substances present in effluent, before it is released into the environment.

Polycyclic aromatic hydrocarbons (PAHs) are produced by the incomplete combustion of organic materials and they are considered environmental contaminants globally worrying (Ohe et al., 2004; Sun and Zang, 2012). The main sources of contamination by PAHs are from domestic and industrial waste dumps into the atmospheric and water resources (Souza et al., 2012). Many environmental studies have confirmed that PAHs present mutagenic and carcinogenic action (Harvey, 1997; Linsak et al., 2011; Ana et al., 2012).

An important feature of oil refinery wastewater is the high concentration of organic and inorganic pollutants, which even in concentrations lower than lethal can cause damage to both terrestrial and aquatic biota (Santaella et al., 2009). Nogueira (2013) reported that, although the components of the oil refinery effluent may vary, the main contaminants found are: free and emulsified hydrocarbons; phenols, including methyl and diethyl-phenols; mercaptans, sulfides and ammonia.

The biological treatment of industrial wastewater is applied by the Paulínia-SP/Brazil oil refinery, because it is a low cost, extremely versatile and very effective option for promoting oxidation of many organic pollutants. The microorganisms used in this process, mainly bacteria, decompose organic matter to inert inorganic compounds, through anaerobic or aerobic metabolic processes (Teixeira and Jardim, 2004). Stabilization ponds are defined as artificially created water bodies for the storage of effluent containing large loads of organic pollutants. In these systems, there are bacteria that under anaerobic conditions transform putrid organic matter into more stable organic mineral compounds, as well as releasing $\mathrm{CO}_{2}$, water, and organic acids. For this reason, monitoring each step of the effluent treatment is necessary to ensure its efficiency.

Both genotoxic and/or mutagenic compounds can interact with other elements of the environment to form a complex environmental mixture. Such mixtures may induce adverse effects on exposed organisms, including injuries affecting human health (Dearfield et al., 2002). Bioactive substances may be toxic to genetic material and therefore induce both structural and numerical chromosomal aberrations (Russel, 2002).

Allium cepa species has been considered an important test organism for evaluation of genotoxicity and mutagenicity of environmental pollutants. These effects are evaluated by the investigated agent's potential to induce chromosomal and/or micronuclei aberrations in meristem cells and micronuclei in cells of the F1 region of the root (Hoshina and Marin-Morales, 2009; Bianchi et al., 2011, 2015a; Magdaleno et al., 2014). The A. cepa test has advantages such as high sensitivity, low cost, easy evaluation of microscopic and macroscopic parameters and a positive correlation with other tests developed with mammals (Fiskesjö, 1985; Palmieri et al., 2016).

The use of laboratory animals in scientific experiments is becoming increasingly rigorous and thus the development and standardization of in vitro tests to detect the toxicity of chemicals has become necessary (Rogero et al., 2003). In vitro tests are more indicated for scientific research because there are no ethical principles to be followed, they make possible a reduction in the number of experimental animals, and they lower the costs of the operation and infrastructure. Studies performed with in vitro systems have gained prominence among test systems due to their providing controllable experimental conditions, such as availability, reproducibility and ease of obtaining the results (Rabello-Gay and Rodrigues, 1991).

Many studies evaluating the genotoxic and mutagenic potential of environmental pollutants are using mammalian cell cultures as test systems (Matsumoto et al., 2005; Lagerqvist et al., 2011; Manzano et al., 2015; Bianchi et al., 2015b). Among in vitro systems, Chinese Hamster Ovary cells ( $\mathrm{CHO}-\mathrm{K} 1$ ) have been considered a sensitive test system to assess the toxicity of contaminated samples (Matsumoto et al., 2005; Nirogi et al., 2014; Tian et al., 2015).

Micronuclei (MN) are cellular structures resulting from different actions, such as those that have a direct action on the genetic material of an exposed organism, promoting rupture of this molecule and generating acentric fragments (clastogenic action) or those that have indirect action, where the inducing agent interacts with other molecules or cellular structures, such as mitotic spindle proteins, leading to the loss of whole chromosomes from the cellular chromosomal set (aneugenic action) (Fenech, 2000; KirschVolders et al., 2003; Fernandes et al., 2007, 2009). The MN test, performed with mammalian cells, is considered an important tool for assessing the commitment of ecosystems and is considered one of the most efficient environmental analysis tests (Fenech, 2000).

This study aims to evaluate the possible impacts that an oil refinery can promote on the surrounding water resources. For this purpose, this study investigates the genotoxic and mutagenic potential of the wastewater samples from the Paulinia-SP oil refinery, before and after treatment by the company, and of samples of the river water involved in the refinery activities (Jaguari River - water collection from the refinery and Atibaia River - refinery effluent receiver). For this evaluation, chromosomal aberration (CA) and MN tests were performed on $A$. cepa meristematic cells, MN tests on A. cepa F1 cells and on Chinese Hamster Ovary (CHO-K1) cell cultures. The ecotoxicological assessments conducted in this study also provide a basis for estimating the effectiveness of the biological treatments and the success of the stabilization pond in the removal of the high-toxicity organic contaminants present in the wastewater from oil refineries.

\section{Material and methods}

\subsection{Location of the study area and collection of water samples}

The Atibaia and Jaguari Rivers belong to the PCJ (Piracicaba, Capivari, and Jundiaí) hydrographic basin and they are important rivers of Brazil's São Paulo State. These rivers cross the city of Paulínia-SP, a city that, besides having a high population density, 
has a large industrial area, in particular the largest petroleum refinery of the Petrobras system. This refinery collects water from the Jaguari River and, after using it in the petroleum refining process, treats its effluent (physico-chemical, biological and stabilization tanks) before discharging into the Atibaia River.

Water and effluent samples were collected at six different points related to the petroleum refinery as follows: Site 1 - water collection point for refinery activities outside the refinery in Jaguari River (Lat: $22^{\circ} 41^{\prime} 48^{\prime \prime}$, Long: $47^{\circ} 08^{\prime} 59^{\prime \prime}$ ); Site 2 - collection point inside the refinery (Lat: $22^{\circ} 44^{\prime} 18^{\prime \prime}$, Long: $47^{\circ} 07^{\prime} 17^{\prime \prime}$ ), after the physico-chemical treatment (first treatment carried out on the refinery effluent); Site 3 - entrance to the refinery stabilization pond, after the biological treatment with activated sludge (Lat: $22^{\circ} 44^{\prime} 26^{\prime \prime}$, Long: $\left.47^{\circ} 07^{\prime} 33^{\prime \prime}\right)$; Site 4 - exit from the stabilization pond (final effluent) (Lat: $22^{\circ} 44^{\prime} 22^{\prime \prime}$, Long: $47^{\circ} 07^{\prime} 03^{\prime \prime}$ ); Site $5-$ water from the Atibaia River, $200 \mathrm{~m}$ upstream of the discharge of the refinery effluent (Lat: $22^{\circ} 41^{\prime} 28^{\prime \prime}$, Long: $47^{\circ} 07^{\prime} 22^{\prime \prime}$ ); Site $6-$ water from the Atibaia River - about $800 \mathrm{~m}$ downstream of the discharge of refinery effluent (zone of completed mixture of effluent with river waters) (Lat: $22^{\circ} 44^{\prime} 22.3^{\prime \prime}$, Long: $47^{\circ} 07^{\prime} 40.8^{\prime \prime}$ ).

\subsection{Biological materials used for genotoxicity evaluation of the samples}

This study was performed at the Mutagenesis Laboratory of the Biosciences Institute of UNESP in Ri Claro. Seeds of the species Allium cepa ( $2 \mathrm{n}=16$ chromosomes) of Baia Periforme variety and cells of Chinese Hamster Ovary (CHO-K1) were used in genotoxic and mutagenic assays.

\subsection{Allium cepa bioassay}

The A. cepa test was developed based on the protocol established by Grant (1982), with some adjustments. In this trial, the seeds of A. cepa were exposed in water samples and effluents collected in 2010 and 2011, in three distinct periods, which characterized different climatic conditions typical of southeastern Brazil: August 2010 (winter, cold and dry), March 2011 (summer, hot and rainy) and May 2011 (autumn, mild and dry). Seed germination was performed in individual Petri dishes containing water samples and effluent collected at Sites 1 to 6 cited above. Controls were performed with ultrapure water (negative control) and an aqueous solution of methyl methane sulphonate (MMM: $4 \times 10^{-4} \mathrm{M}$ ) (positive control).

After germination, about half of the onion roots of about $1.5 \mathrm{~cm}$ in length were collected and fixed in Carnoy 3:1 (3 parts ethanol to 1 part acetic acid $\mathrm{v} / \mathrm{v}$ ). The other halves of the rootlets were transferred for $48 \mathrm{~h}$ to Petri dishes containing ultrapure water to test the recovery potential of the organism after normalization to environmental conditions. This treatment is indicated to estimate the type of damage (repairable or non-repairable) that a xenobiont, or a complex environmental sample, can induce in the exposed organism (Leme and Marin-Morales, 2008). Then, all the radicles were collected and fixed in Carnoy 3:1 for subsequent slide preparation.

To prepare the slides, the fixed roots were submitted to acid hydrolysis with $1 \mathrm{~N} \mathrm{HCl}$ at $60{ }^{\circ} \mathrm{C}$ and stained with Schiff reagent. Then, the meristematic and $\mathrm{F}_{1}$ (located about $1 \mathrm{~mm}$ above the meristematic region) regions of the radicles were sectioned, covered with a coverslip and carefully squashed in a drop of $2 \%$ acetic carmine. The coverslips were removed in liquid nitrogen and the slides permanently mounted with a synthetic resin for subsequent microscopic analysis.

For the analysis of genotoxic and mutagenic effects, 5000 cells of each cellular type were counted per treatment. Different types of chromosomal aberration such as losses, breaks, chromosome stickiness, bridges, delays, nuclear buds and micronuclei were considered in different phases of the cell cycle of the meristematic cells, but only micronuclei were considered in $\mathrm{F}_{1}$ cells. The data obtained were submitted to the non-parametric statistical test of Mann-Whitney $(\mathrm{p}<0.05)$, which allows comparison of treatments with the negative control.

\subsection{Maintenance of the CHO-K1 cells for the MN test}

The CHO-K1 cells were cultivated in DMEM/F12 medium (Dulbecco's Modified Eagle Medium: Nutrient Mixture F12; Invitrogen) with antibiotic/antimycotic and supplemented with $10 \%$ fetal bovine serum (FBS; Cultilab). The culture flasks $\left(25 \mathrm{~cm}^{2}\right)$ were kept under controlled temperature $\left(37^{\circ} \mathrm{C}\right)$. After cellular growth, the cells were washed with phosphate buffered saline (PBS) and trypsinized with Trypsin-EDTA $0.025 \%$. The pre-flasks were prepared with about $1 \times 10^{6}$ cells each and after $24 \mathrm{~h}$ of stabilization, the cells were exposed to the effluents and water samples collected and to the controls.

\subsubsection{Treatment determination}

For MN test in CHO-K1 cells, samples were collected in three distinct periods of 2011 (May - autumn, mild and dry, July winter, cold and dry, and November - spring, hot and rainy). After $\mathrm{pH}$ correction of all samples to about 7.3, they were filtered through a sulfone polyester membrane syringe $(33 \mathrm{~mm}$ diameter and $0.22 \mathrm{mM}$ of porosity - Millipore $\left.{ }^{\mathbb{B}}\right)$. The negative control treatment was performed by exposing the cells to PBS and the positive control was performed with aqueous MMS solution $\left(4 \times 10^{-4} \mathrm{M}\right)$. All tests were performed in triplicate and an exposure period of $3 \mathrm{~h}$.

The volume of samples and controls used in the tests was $20 \%$ of the total volume of the culture flask, as suggested by Reifferscheid et al. (2008), who describe that the change in osmolality resulting from the addition of $20 \%$ of sample in cell culture did not induce cytotoxic and/or genotoxic effects in exposed cells.

\subsubsection{MN test with cytokinesis block in $\mathrm{CHO}-\mathrm{K} 1$ cells}

After the treatment described above, the flasks were washed with PBS and a new culture medium containing $3 \mathrm{mg} / \mathrm{mL}$ cytochalasin B per flask was added for the induction of binucleated cells. Cells remained in this medium for $18 \mathrm{~h}$. The cells were subjected to $0.025 \%$ Trypsin-EDTA and the entire contents of the flask transferred to a Falcon ${ }^{\circledR}$ tube, where a drop of $40 \%$ formaldehyde was added. The tubes were homogenized and centrifuged at $1000 \mathrm{rpm}$ for $5 \mathrm{~min}$. After the supernatant was discarded, $1.5 \mathrm{~mL}$ of $1 \%$ sodium citrate solution was added and homogenized. The tubes were centrifuged and the cells were fixed by the addition of $5 \mathrm{~mL}$ of Carnoy 3:1 (3 parts ethanol to 1 part acetic acid v/v). For the slide preparation, the cell suspension was dropped on prewashed slides and covered with a film of distilled water at $4{ }^{\circ} \mathrm{C}$. The slides were stained with Giemsa $5 \%$ for 10 min.

For the MN induction analysis, three slides of each treatment were counted. For each slide, 1000 binucleated cells with nuclear membrane and cytoplasm intact, with nuclei of similar size, without overlap and with the same staining pattern were counted, totaling 3000 cells per treatment. The relationship between normal binucleated cells and binucleated cells with MN, bridge and/or nuclear bud, was evaluated according to Fenech et al. (2003). The significance of the results was estimated by ANOVA: one criterion/ Dunnett's test $(\mathrm{p}<0.001)$. 


\subsection{Physico-chemical and chemical analysis of water and effluent samples}

The sampling of superficial water collected at the points studied was performed according to the protocol proposed by CETESB (1987). The physico-chemical analysis of water and effluent samples was carried out at the Chemistry and Microbiology Laboratory of the Center for Environmental Studies (CEA) of the São Paulo State Universidad (UNESP - Rio Claro, SP- Brazil), according to the Standard Methods for the Examination of Water and Wastewater and the American Water Works Association (AWWA, 1998). Chemical analyses were performed on all the water and effluent samples. In this analysis were quantified the parameters of temperature, conductivity, $\mathrm{pH}$, settleable solids, suspended soluble solids, volatile material, turbidity, dissolved oxygen (OD), chemical oxygen demand (COD), biochemical oxygen demand (BOD), chlorides, nitrites, nitrates, sulfides, arsenic, selenium, mercury, barium, aluminum, calcium, iron, potassium, magnesium, sodium, phosphorus, silicon and strontium.

\section{Results}

\subsection{Allium cepa}

The results from the CA and MN test are presented in Table 1. Meristematic cells of $A$. cepa exposed to effluent and water samples showed that only Site 2 (collection point inside the refinery after the physico-chemical treatment) collected in March 2011 presented higher frequencies of the CA and MN than the negative control. This period (July 2011) was characterized by warmer and rainier weather than the other periods studied.

For the other collection periods (August 2010; May 2011) none of the samples showed evidence of genotoxicity and mutagenicity when compared to the negative control.
The meristematic and F1 cells of the roots used in the genotoxicity and mutagenicity tests with river water and the refinery effluent samples, after a recovery period of $48 \mathrm{~h}$ in milli-Q water, did not show significant CA and MN in the different periods, with the exception of Site 1 (August 2010) and Site 2 (March 2011). Considering the MN induction by the samples collected in March 2011 and the non-induction of this anomaly after $48 \mathrm{~h}$ recovery with water at the same site, we suggest that the period used for recovery was enough to repair the damage promoted by the sample.

The roots exposed to the sample from Site 6 (Atibaia River water - about $800 \mathrm{~m}$ downstream from the refinery effluent discharge), collected in March 2011, when submitted to 48 h recovery period, did not respond to conventional staining or were in the process of cell death or in interphase, which prevented the recognition of cells with chromosomal aberrations.

In this study, the analysis of the F1 cell region was also performed to verify if the damage (presence of $\mathrm{MN}$ ) promoted by the tested samples were fixed in the daughter cells. Thus, it was observed that none of the samples showed higher values of the MN induction when compared to the negative control.

\subsection{MN test with cytokinesis block in $\mathrm{CHO}-\mathrm{K} 1$ cells}

The results obtained from the assays performed with mammalian cell (CHO-K1) cultures indicated a significant induction of MN by the effluent sample from Site 2 (after the first treatment carried out on the refinery), in the three collections performed in this study (autumn, winter, spring) (Table 2). Samples from the other collection points did not induce the formation of the $\mathrm{MN}$ in $\mathrm{CHO}-\mathrm{K} 1$, indicating that none of them presented any substance with mutagenic potential. From these analyses, it was observed that the three collections presented the same pattern of alterations, which shows that there was no infiuence of the seasons in the toxicity of samples.

Table 1

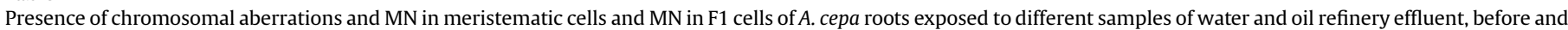
after the recovery period (48 $\mathrm{h})$.

\begin{tabular}{|c|c|c|c|c|c|c|c|}
\hline & & \multicolumn{3}{|l|}{ Raw Sample } & \multicolumn{3}{|c|}{ Recovery (Mili-Q Water) } \\
\hline & & $\mathrm{CA}$ & MN & MN F1 & $\mathrm{CA}$ & $\mathrm{MN}$ & MN F1 \\
\hline \multirow[t]{8}{*}{ August 2010} & $\mathrm{NC}$ & $1.08 \pm 0.73$ & $0.00 \pm 0.00$ & $1.92 \pm 1.08$ & $1.21 \pm 0.89$ & $0.26 \pm 0.56$ & $2.04 \pm 1.27$ \\
\hline & PC & $2.91 \pm 2.50^{*}$ & $2.14 \pm 1.18^{*}$ & $5.95 \pm 2.11^{*}$ & $1.19 \pm 0.96$ & $1.40 \pm 1.16^{*}$ & $4.90 \pm 1.63^{*}$ \\
\hline & Site 1 & $1.63 \pm 1.35$ & $0.48 \pm 0.68$ & $3.49 \pm 1.80$ & $2.51 \pm 0.62^{*}$ & $0.64 \pm 0.85$ & $3.77 \pm 1.47$ \\
\hline & Site 2 & $1.74 \pm 0.76$ & $0.19 \pm 0.69$ & $1.47 \pm 1.26$ & $1.67 \pm 0.98$ & $0.91 \pm 0.95$ & $2.26 \pm 1.55$ \\
\hline & Site 3 & $1.65 \pm 1.21$ & $0.48 \pm 0.68$ & $2.25 \pm 1.19$ & $2.23 \pm 1.02$ & $0.26 \pm 0.42$ & $3.09 \pm 1.42$ \\
\hline & Site 4 & $2.06 \pm 1.26$ & $0.29 \pm 0.65$ & $2.57 \pm 1.57$ & $1.73 \pm 1.03$ & $0.91 \pm 1.38$ & $1.61 \pm 0.75$ \\
\hline & Site 5 & $1.06 \pm 0.78$ & $1.35 \pm 2.36$ & $1.75 \pm 1.23$ & $1.22 \pm 0.83$ & $0.46 \pm 0.65$ & $3.49 \pm 2.21$ \\
\hline & Site 6 & $1.06 \pm 1.15$ & $0.48 \pm 0.67$ & $1.85 \pm 1.59$ & $1.70 \pm 1.44$ & $0.55 \pm 0.62$ & $2.15 \pm 1.58$ \\
\hline \multirow[t]{8}{*}{ March 2011} & $\mathrm{NC}$ & $0.74 \pm 0.59$ & $0.18 \pm 0.39$ & $2.91 \pm 1.21$ & $1.00 \pm 0.80$ & $1.30 \pm 1.26$ & $2.01 \pm 1.14$ \\
\hline & PC & $5.44 \pm 2.93^{*}$ & $5.43 \pm 5.57^{*}$ & $5.43 \pm 5.58$ & $2.10 \pm 1.31^{*}$ & $5.23 \pm 2.12^{*}$ & $13.67 \pm 4.43 *$ \\
\hline & Site 1 & $0.93 \pm 1.02$ & $0.45 \pm 0.63$ & $2.95 \pm 2.44$ & $1.43 \pm 0.98$ & $0.63 \pm 0.59$ & $2.17 \pm 1.40$ \\
\hline & Site 2 & $2.89 \pm 1.15^{*}$ & $1.57 \pm 2.07^{*}$ & $2.12 \pm 2.40$ & $2.21 \pm 1.40^{*}$ & $1.42 \pm 1.26$ & $4.39 \pm 1.70$ \\
\hline & Site 3 & $0.83 \pm 0.68$ & $0.27 \pm 0.43$ & $3.05 \pm 1.37$ & $1.42 \pm 0.73$ & $1.09 \pm 1.22$ & $2.53 \pm 2.47$ \\
\hline & Site 4 & $1.48 \pm 0.97$ & $0.19 \pm 0.40$ & $3.04 \pm 2.10$ & $1.54 \pm 0.99$ & $0.67 \pm 0.91$ & $2.78 \pm 2.35$ \\
\hline & Site 5 & $1.83 \pm 1.01$ & $0.24 \pm 0.54$ & $1.76 \pm 1.45$ & $1.76 \pm 1.56$ & $1.22 \pm 0.89$ & $2.75 \pm 1.70$ \\
\hline & Site 6 & $1.19 \pm 1.06$ & $0.08 \pm 0.31$ & $1.95 \pm 1.32$ & $0.00 \pm 0.00$ & $0.00 \pm 0.00$ & $0.00 \pm 0.00$ \\
\hline \multirow[t]{8}{*}{ May 2011} & $\mathrm{NC}$ & $1.23 \pm 1.06$ & $0.64 \pm 0.91$ & $1.36 \pm 1.18$ & $1.39 \pm 0.67$ & $1.01 \pm 1.30$ & $1.55 \pm 1.17$ \\
\hline & PC & $8.01 \pm 5.93^{*}$ & $12.47 \pm 10.29 *$ & $2.03 \pm 1.41$ & $3.76 \pm 1.96^{*}$ & $7.41 \pm 3.43^{*}$ & $8.59 \pm 2.86^{*}$ \\
\hline & Site 1 & $2.64 \pm 2.92$ & $0.97 \pm 1.30$ & $1.08 \pm 0.82$ & $2.68 \pm 1.82$ & $3.53 \pm 4.87$ & $4.69 \pm 7.42$ \\
\hline & Site 2 & $2.41 \pm 1.74$ & $1.48 \pm 1.86$ & $1.85 \pm 2.12$ & $1.08 \pm 1.10$ & $3.06 \pm 5.93$ & $3.86 \pm 3.21$ \\
\hline & Site 3 & $3.07 \pm 2.28$ & $1.02 \pm 2.23$ & $2.73 \pm 3.13$ & $1.65 \pm 1.11$ & $1.50 \pm 0.76$ & $2.43 \pm 2.48$ \\
\hline & Site 4 & $1.04 \pm 0.80$ & $1.39 \pm 1.88$ & $2.15 \pm 1.24$ & $1.48 \pm 0.76$ & $1.12 \pm 0.87$ & $2.05 \pm 1.47$ \\
\hline & Site 5 & $1.80 \pm 1.93$ & $0.81 \pm 1.16$ & $1.81 \pm 1.61$ & $1.16 \pm 0.95$ & $0.64 \pm 0.76$ & $1.43 \pm 1.36$ \\
\hline & Site 6 & $2.15 \pm 1.79$ & $1.58 \pm 1.21$ & $2.62 \pm 1.56$ & $0.83 \pm 0.79$ & $1.87 \pm 1.60$ & $4.18 \pm 2.82$ \\
\hline
\end{tabular}

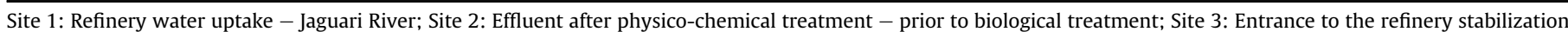

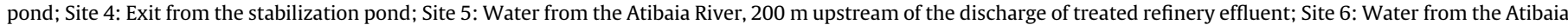
River - about $800 \mathrm{~m}$ downstream of the discharge of treated refinery effluent.

NC: Negative Control; PC: Positive Control; CA: Chromosome Aberrations; MN: micronucleus; MN F1: Micronucleus in F1 cells. *P < 0.05 statistically significant. 
Table 2

Presence of MN test with cytokinesis block in CHO-K1 cells exposed to different samples of water and oil refinery effluents.

\begin{tabular}{|c|c|c|c|c|c|c|c|c|c|}
\hline \multirow[t]{2}{*}{ Treatments } & \multicolumn{3}{|l|}{ May/2011 } & \multicolumn{3}{|l|}{ July/2011 } & \multicolumn{3}{|l|}{ November/2011 } \\
\hline & $\begin{array}{l}\text { MN } \\
(\text { Mean } \pm S D)\end{array}$ & $\begin{array}{l}\text { NBUDs } \\
(\text { Mean } \pm \text { SD) }\end{array}$ & $\begin{array}{l}\text { NPBs } \\
(\text { Mean } \pm \text { SD })\end{array}$ & $\begin{array}{l}\text { MN } \\
(\text { Mean } \pm S D)\end{array}$ & $\begin{array}{l}\text { NBUDs } \\
(\text { Mean } \pm \text { SD) }\end{array}$ & $\begin{array}{l}\text { NPBs } \\
(\text { Mean } \pm \text { SD })\end{array}$ & $\begin{array}{l}\text { MN } \\
(\text { Mean } \pm S D)\end{array}$ & $\begin{array}{l}\text { NBUDs } \\
(\text { Mean } \pm \text { SD })\end{array}$ & $\begin{array}{l}\text { NPBs } \\
(\text { Mean } \pm \text { SD })\end{array}$ \\
\hline $\mathrm{NC}$ & $14.00 \pm 1.00$ & $9.33 \pm 3.51$ & $13.33 \pm 6.81$ & $17.00 \pm 3.61$ & $13.33 \pm 4.16$ & $12.33 \pm 1.53$ & $9.67 \pm 2.89$ & $5.67 \pm 4.62$ & $7.00 \pm 1.73$ \\
\hline PC & $87.00 \pm 8.72^{*}$ & $119.33 \pm 7.64^{*}$ & $110.33 \pm 25.32^{*}$ & $150.36 \pm 23.07^{*}$ & $92.33 \pm 9.29^{*}$ & $40.00 \pm 3.46^{*}$ & $157.67 \pm 17.01^{*}$ & $80.00 \pm 14.11^{*}$ & $36.67 \pm 8.33^{*}$ \\
\hline Site 1 & $25.67 \pm 2.89$ & $9.67 \pm 3.05$ & $19.00 \pm 1.00$ & $29.00 \pm 2.00$ & $15.33 \pm 4.04$ & $17.00 \pm 2.65$ & $9.33 \pm 1.15$ & $6.33 \pm 0.58$ & $10.00 \pm 3.00$ \\
\hline Site 2 & $48.33 \pm 3.79^{*}$ & $36.67 \pm 0.58^{*}$ & $23.00 \pm 1.73$ & $59.67 \pm 3.51^{*}$ & $42.67 \pm 12.22^{*}$ & $29.67 \pm 4.04^{*}$ & $32.33 \pm 1.53^{*}$ & $12.33 \pm 5.91$ & $24.67 \pm 8.08$ \\
\hline Site 3 & $29.33 \pm 11.85$ & $14.33 \pm 7.57$ & $28.67 \pm 8.50$ & $23.00 \pm 7.81$ & $17.00 \pm 3.46$ & $9.00 \pm 2.65$ & $18.00 \pm 2.65$ & $7.67 \pm 0.58$ & $15.67 \pm 2.89$ \\
\hline Site 4 & $21.67 \pm 3.05$ & $15.33 \pm 3.21$ & $19.33 \pm 3.79$ & $26.00 \pm 4.36$ & $12.33 \pm 0.60$ & $6.00 \pm 2.65$ & $21.00 \pm 3.61$ & $8.33 \pm 2.08$ & $13.00 \pm 1.00$ \\
\hline Site 5 & $38.00 \pm 4.36$ & $18.00 \pm 6.56$ & $30.00 \pm 5.29$ & $34.67 \pm 7.77$ & $25.67 \pm 4.04^{*}$ & $18.67 \pm 2.52$ & $23.33 \pm 4.16$ & $7.67 \pm 2.52$ & $20.00 \pm 2.00$ \\
\hline Site 6 & $35.00 \pm 3.00$ & $24.00 \pm 5.20$ & $26.33 \pm 4.04$ & $39.67 \pm 3.05$ & $22.67 \pm 2.08^{*}$ & $23.33 \pm 6.43$ & $18.00 \pm 1.00$ & $8.00 \pm 1.00$ & $12.70 \pm 3.06$ \\
\hline
\end{tabular}

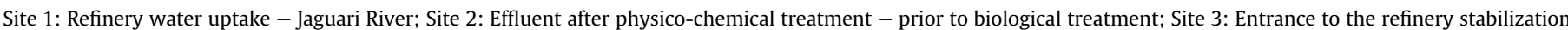

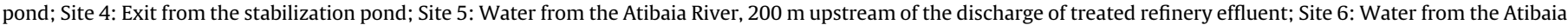

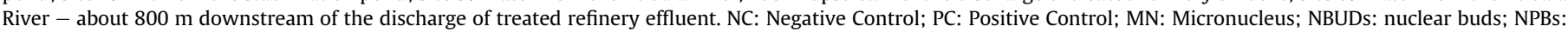
nucleoplasmic. ${ }^{*} \mathrm{p}<0.001$ statistically significant.

The presence of nuclear buds (NBUDs) and nucleoplasmic bridges (NPBs) were considered in this study as genotoxicity endpoints, and the results are shown in Table 2. The effluent samples collected from Site 2 in May 2011 (autumn, mild and dry) and those collected from Sites 2, 5 and 6 in July 2011 induced significant NBUDs in the CHO-K1 cells. For the NPBs index, only the effluent samples collected from Site 2 in July 2011 presented significant induction of this change when compared with the negative control.

\subsection{Physico-chemical and chemical analysis}

Physico-chemical and chemical parameters obtained for water samples from the Atibaia and Jaguari Rivers and from different treatment processes of the petroleum refinery collected at three different seasons of the year are shown in Tables 3 and 4 .

In order to evaluate the water quality of the rivers (Atibaia and Jaguari) and of the effluent treated by the refinery, the maximum limits established by Brazilian legislation described by CONAMA (Brazilian National Environmental Council) Resolution 357/2005 related to freshwater rivers class 2 and the Resolution 430/2011 to effluent discharge were followed.

The analysis in Table 3 allows us to observe that there was not much pH change for the freshwater rivers and treated wastewater, this parameter being kept close to neutrality. Electrical conductivity values showed high levels in all samples, except the sample collected in the Jaguari River, where values ranged from 58.70 to $110.6 \mu \mathrm{S} / \mathrm{cm}$. However, it can be observed that although the conductivity levels were high for different refinery effluents and for the waters of the Atibaia River, there was maintenance of the conductivity indices at points downstream of the refinery effluent discharging. This indicates that the refinery effluent did not interfere with the quality water of the Atibaia River. The analysis of dissolved oxygen for the samples from the Atibaia and Jaguari Rivers presented values that are in accordance with Brazilian law, except for samples collected in July 2011.

Through the metal analysis performed on the effluent and river water samples related to the petroleum refinery, high values were observed for metals such as aluminum ( $\mathrm{Al}$ ) and iron ( $\mathrm{Fe}$ ) at different collection sites and periods. However, arsenic, selenium, mercury, and barium in all samples were within the limits established by Brazilian law (CONAMA 357/2005).

Concerning other inorganic nutrients, phosphorus was also above the permitted value for all water samples collected in the Atibaia and Jaguari Rivers. Although the chloride indices were high in the analyses performed on refinery effluent samples, the waters of the Atibaia River maintained this parameter within the limits of the CONAMA 357/05 legislation.

\section{Discussion}

Bioassays have been increasingly applied in the evaluation of environmental pollution effects, by to estimate the commitments that chemical agents can cause both in organisms and ecosystems exposed to pollution (Van der Oost et al., 2003; Lemos et al., 2007; Hoshina et al., 2008).

The samples collected this study may contain PAHs from the petroleum refinery wastewater, which contains substances that may interfere with the quality of the river that receives this effluent. According to Aina et al. (2006), the PAHs present in crude oil are toxic, with recognized mutagenic and carcinogenic potential.

In addition to PAHs, petroleum refinery wastewater may contain various chemicals with toxic potential such as greases and oils, phenols, cresols, xylenes, sulfides, ammonia, solid cyanide suspensions, nitrogen compounds and metals such as chromium, iron, nickel, copper, molybdenum, selenium, vanadium and zinc (Brown and Donelly, 1984). Due to this pollution potential of oil refineries, its wastewater must undergo a rigorous treatment system, besides a constant monitoring of the rivers around the plant.

A study conducted by Fiskesjö (1985) with benzo[ $\alpha]$ pyrene proved that the A. cepa test system is a suitable test organism to evaluate the genotoxicity of PAHs. The author observed that cell metabolism of these contaminants in A. cepa occurs due to the presence of an oxidase coenzyme system. The plants have been considered as effective biomarkers of environmental pollution. Among them, we can highlight the A. cepa species, because it is an organism that has a system of enzyme cytochrome P450 involved in detoxification processes, which aids in the biotransformation of chemical compounds (Guencheva and Henriquers, 2003).

From the CA analysis performed with $A$. cepa with refinery effluent and water samples, it can be observed that the sample collected from Site 2 (March 2011) presented indications of genotoxic effects. This point corresponds to the raw effluent, which was submitted only to the first (physico-chemical) treatment performed by the company.

The abnormalities observed can be related to the presence of several chemical compounds resulting from the refinery process because the first treatment was not so efficient for reducing toxicity of wastewater. After the treatment with activated sludge and the stabilization pond, the final refinery effluent (Site 4) had the minimum toxicity. As there was not significant CA in the samples collected from Site 4, the efficiency of the refinery treatment system was confirmed. 
Table 3

Results of physical and chemical analysis of samples of water and oil refinery effluents.

\begin{tabular}{|c|c|c|c|c|c|c|c|c|c|c|c|c|c|c|c|c|}
\hline \multirow{2}{*}{\multicolumn{2}{|c|}{$\begin{array}{l}\text { CONAMA N }{ }^{\circ} 357 / \\
2005\end{array}$}} & $\mathrm{pH}$ & $\begin{array}{l}\text { Cond. (uS/ } \\
\mathrm{cm} \text { ) }\end{array}$ & $\begin{array}{l}\text { Temp. } \\
\left({ }^{\circ} \mathrm{C}\right)\end{array}$ & $\begin{array}{l}\text { SS } \\
(\mathrm{mL} / \mathrm{L})\end{array}$ & $\begin{array}{l}\text { SSS (g/ } \\
\mathrm{L})\end{array}$ & $\begin{array}{l}\text { Vol. Mat. } \\
(\mathrm{g} / \mathrm{L})\end{array}$ & \multirow{3}{*}{$\begin{array}{l}\text { Turb. } \\
\text { (NTU) } \\
100\end{array}$} & \multirow{3}{*}{$\begin{array}{l}\begin{array}{l}\text { DO } \\
(\mathrm{mg} / \mathrm{L})\end{array} \\
>5.00\end{array}$} & \multirow[t]{3}{*}{$\begin{array}{l}\text { COD } \\
(\mathrm{mg} / \mathrm{L})\end{array}$} & \multirow{3}{*}{$\begin{array}{l}\text { BOD } \\
(\mathrm{mg} / \mathrm{L}) \\
<5.00\end{array}$} & \multirow{3}{*}{$\begin{array}{l}\text { Chlorides } \\
(\mathrm{mg} / \mathrm{L}) \\
250\end{array}$} & \multirow[t]{3}{*}{$\begin{array}{l}\text { Ammonia } \\
(\mathrm{mg} / \mathrm{L})\end{array}$} & \multirow{3}{*}{$\begin{array}{l}\text { Nitrite } \\
(\mathrm{mg} / \mathrm{L})\end{array}$} & \multirow{3}{*}{$\begin{array}{l}\begin{array}{l}\text { Nitrate } \\
(\mathrm{mg} / \mathrm{L})\end{array} \\
10.0\end{array}$} & \multirow{2}{*}{$\begin{array}{l}\text { Sulfides } \\
(\mu \mathrm{g} / \mathrm{L}) \\
0.002\end{array}$} \\
\hline & & $\begin{array}{l}6.0 \\
-9.0\end{array}$ & & & & & & & & & & & & & & \\
\hline $\begin{array}{l}\text { CONAMA N } \\
2011\end{array}$ & o $430 /$ & $\begin{array}{l}5.0 \\
-9.0\end{array}$ & & $<40$ & & & & & & & & & & & & 1.00 \\
\hline \multirow[t]{6}{*}{$\begin{array}{l}\text { August } \\
2010\end{array}$} & $\begin{array}{l}\text { Site } \\
1\end{array}$ & 7.60 & 107.70 & 20 & 0.10 & 0.1110 & 0.1110 & 12.40 & 6.27 & 7.68 & 7.00 & 7.86 & $*$ & 0.1923 & 2.0554 & 1.00 \\
\hline & $\begin{array}{l}\text { Site } \\
2\end{array}$ & 7.91 & 2740.0 & 30 & 0.70 & 20.230 & 20.230 & 80.00 & 0.60 & 1920.00 & 1792.00 & 712.97 & $*$ & $* *$ & 9.4430 & 750.00 \\
\hline & $\begin{array}{l}\text { Site } \\
3\end{array}$ & 8.20 & 2780.00 & 30 & 0.10 & 18.370 & 18.370 & 21.00 & 5.82 & 128.00 & 30.70 & 762.14 & $*$ & $* *$ & 6.2211 & 9.00 \\
\hline & $\begin{array}{l}\text { Site } \\
4\end{array}$ & 8.39 & 2800.00 & 24 & 0.10 & 20.560 & 20.560 & 11.50 & 5.79 & 160.00 & 30.30 & 774.43 & $*$ & 0.0806 & 5.2786 & 7.00 \\
\hline & $\begin{array}{l}\text { Site } \\
5\end{array}$ & 7.84 & 295.00 & 20 & 0.10 & 0.2270 & 0.2270 & 16.60 & 6.33 & 12.48 & 11.40 & 20.65 & * & 0.2562 & 2.2014 & 1.00 \\
\hline & $\begin{array}{l}\text { Site } \\
6\end{array}$ & 7.84 & 347.00 & 20 & 0.10 & 0.2080 & 0.2080 & 17.00 & 6.07 & 14.40 & 12.50 & 33.43 & $*$ & 0.2434 & 2.2264 & 4.00 \\
\hline \multirow[t]{6}{*}{$\begin{array}{l}\text { March } \\
2011\end{array}$} & $\begin{array}{l}\text { Site } \\
1\end{array}$ & 7.17 & 56.70 & 25 & $<0.1$ & 0.2830 & 0.2670 & 19.48 & 5.35 & 14.56 & 7.80 & 2.95 & 0.58 & 0.0103 & 0.3407 & 9.00 \\
\hline & $\begin{array}{l}\text { Site } \\
2\end{array}$ & 7.33 & 2380.00 & 31 & 0.30 & 16.250 & 0.3450 & 25.85 & 2.83 & 600.00 & 200.00 & 700.68 & 41.70 & $* *$ & 13.1756 & 157.00 \\
\hline & $\begin{array}{l}\text { Site } \\
3\end{array}$ & 8.06 & 1740.00 & 29 & $<0.1$ & 13.720 & 0.3270 & 20.70 & 1.50 & 120.00 & 52.70 & 442.53 & 0.59 & 0.2027 & 2.4426 & 9.00 \\
\hline & $\begin{array}{l}\text { Site } \\
4\end{array}$ & 7.84 & 1930.00 & 29 & $<0.1$ & 13.800 & 0.2860 & 17.65 & 5.79 & 120.00 & 53.40 & 516.29 & 0.90 & 0.4533 & 2.4760 & 7.00 \\
\hline & $\begin{array}{l}\text { Site } \\
5\end{array}$ & 7.40 & 174.00 & 25 & 0.10 & 0.2410 & 0.1370 & 25.63 & 7.48 & 12.48 & 11.60 & 8.85 & 1.17 & 0.1596 & 1.0879 & 4.00 \\
\hline & $\begin{array}{l}\text { Site } \\
6\end{array}$ & 7.51 & 173.00 & 25 & $<0.1$ & 0.7440 & 0.6790 & 23.58 & 7.63 & 24.96 & 8.70 & 12.78 & 1.06 & 0.1628 & 1.0920 & 9.00 \\
\hline \multirow[t]{6}{*}{ May 2011} & $\begin{array}{l}\text { Site } \\
1\end{array}$ & 7.60 & 100.90 & 20 & $<0.1$ & 0.1340 & 0.0740 & 19.48 & 10.14 & 8.32 & 6.50 & 5.90 & 1.26 & 0.1293 & 1.3750 & 6.00 \\
\hline & $\begin{array}{l}\text { Site } \\
2\end{array}$ & 7.46 & 2400.00 & 30 & 1.90 & 19.660 & 0.6740 & 25.85 & 5.34 & 552.00 & 484.00 & 565.46 & 37.15 & $* *$ & 13.3841 & 370.00 \\
\hline & $\begin{array}{l}\text { Site } \\
3\end{array}$ & 7.90 & 1960.00 & 29 & 0.10 & 14.400 & 0.4540 & 20.70 & 9.36 & 110.40 & 31.20 & 467.12 & 0.69 & 0.0135 & 3.5103 & 8.00 \\
\hline & $\begin{array}{l}\text { Site } \\
4\end{array}$ & 7.90 & 1770.00 & 26 & $<0.1$ & 12.720 & 0.3880 & 17.65 & 7.96 & 128.80 & 32.30 & 381.07 & 1.50 & 0.1620 & 2.5844 & 10.00 \\
\hline & $\begin{array}{l}\text { Site } \\
5\end{array}$ & 7.56 & 256.50 & 20 & $<0.1$ & 0.1800 & 0.0760 & 25.63 & 9.16 & 9.36 & 8.50 & 14.75 & 2.24 & 0.1796 & 1.4674 & 5.00 \\
\hline & $\begin{array}{l}\text { Site } \\
6\end{array}$ & 7.68 & 257.50 & 20 & 0.20 & 0.1200 & 0.1160 & 23.58 & 8.53 & 11.44 & 10.00 & 17.70 & 2.53 & 0.1851 & 1.5174 & 8.00 \\
\hline \multirow[t]{6}{*}{ July 2011} & $\begin{array}{l}\text { Site } \\
1\end{array}$ & 7.99 & 110.6 & 18 & $<0.1$ & 0.3920 & 0.3160 & 19.48 & 3.47 & 17.92 & 12.20 & 7.87 & 0.77 & 0.1636 & 1.9650 & 10.00 \\
\hline & $\begin{array}{l}\text { Site } \\
2\end{array}$ & 7.77 & 2430.0 & 25 & 0.30 & 21.540 & 0.4940 & 25.85 & 2.68 & 1408.00 & 1300.00 & 540.87 & 22.60 & 0.0487 & 11.7663 & 290.00 \\
\hline & $\begin{array}{l}\text { Site } \\
3\end{array}$ & 8.32 & 2440.0 & 25 & $<0.1$ & 17.720 & 0.4260 & 20.70 & 2.92 & 140.80 & 33.30 & 540.87 & 2.88 & 0.0742 & 3.7110 & 15.00 \\
\hline & $\begin{array}{l}\text { Site } \\
4\end{array}$ & 8.47 & 2630.0 & 21 & $<0.1$ & 18.120 & 0.2500 & 17.65 & 2.72 & 105.60 & 28.00 & 614.63 & 3.22 & 0.0375 & 3.5041 & 28.00 \\
\hline & $\begin{array}{l}\text { Site } \\
5\end{array}$ & 8.10 & 340.3 & 18 & $<0.1$ & 0.4100 & 0.0840 & 25.63 & 3.54 & 22.4 & 14.70 & 17.70 & 1.95 & 0.2035 & 2.1734 & 25.00 \\
\hline & $\begin{array}{l}\text { Site } \\
6\end{array}$ & 7.89 & 358.1 & 18 & $<0.1$ & 0.3960 & 0.1300 & 23.58 & 3.28 & 29.12 & 20.40 & 21.64 & 2.21 & 0.2043 & 2.2008 & 21.00 \\
\hline \multirow[t]{6}{*}{$\begin{array}{l}\text { November } \\
2011\end{array}$} & $\begin{array}{l}\text { Site } \\
1\end{array}$ & 7.52 & 101.5 & 23 & 0.40 & 0.3280 & 0.2180 & 49.0 & 6.23 & 24.96 & 18.50 & 4.94 & 0.69 & 0.2075 & 1.5883 & 0.032 \\
\hline & $\begin{array}{l}\text { Site } \\
2\end{array}$ & 7.4 & 1919 & 23 & 0.10 & 15.620 & 0.4120 & 80.0 & 0.48 & 1568.00 & 1364.00 & 457.12 & 27.10 & 0.0000 & 0.7328 & 0.178 \\
\hline & $\begin{array}{l}\text { Site } \\
3\end{array}$ & 8.05 & 1985 & 29 & $<0.1$ & 13.460 & 0.3240 & 48.0 & 5.34 & 196.00 & 33.50 & 37.06 & 34.60 & 0.2266 & 11.1321 & 0.029 \\
\hline & $\begin{array}{l}\text { Site } \\
4\end{array}$ & 8.63 & 1976 & 28 & 0.10 & 14.780 & 0.3060 & 39.0 & 10.63 & 235.20 & 29.10 & 382.99 & 13.47 & 27.887 & 2.9264 & 0.021 \\
\hline & $\begin{array}{l}\text { Site } \\
5\end{array}$ & 7.87 & 186.1 & 23 & 0.10 & 0.2320 & 0.1580 & 80.0 & 6.08 & 26.00 & 15.30 & 4.94 & 0.77 & 0.2338 & 5.6039 & 0.023 \\
\hline & $\begin{array}{l}\text { Site } \\
6\end{array}$ & 7.61 & 159.0 & 29 & 0.20 & 0.2340 & 0.0460 & 80.0 & 6.08 & 20.80 & 18.30 & 10.87 & 0.77 & 0.2450 & 0.8829 & 0.030 \\
\hline
\end{tabular}

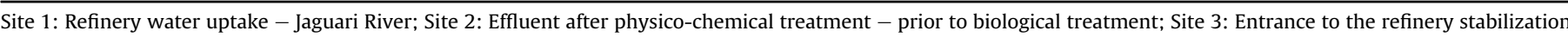

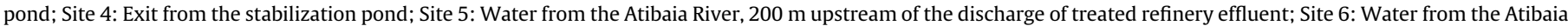

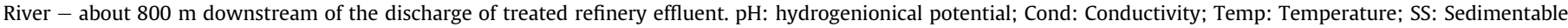

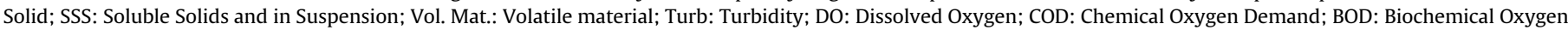
Demand. $\left({ }^{*}\right)$ Technical problems with the equipment; $\left({ }^{* *}\right)$ Low detection level sample. 
Table 4

Results of metals and others inorganic nutrients detection in samples of water and oil refinery effluents.

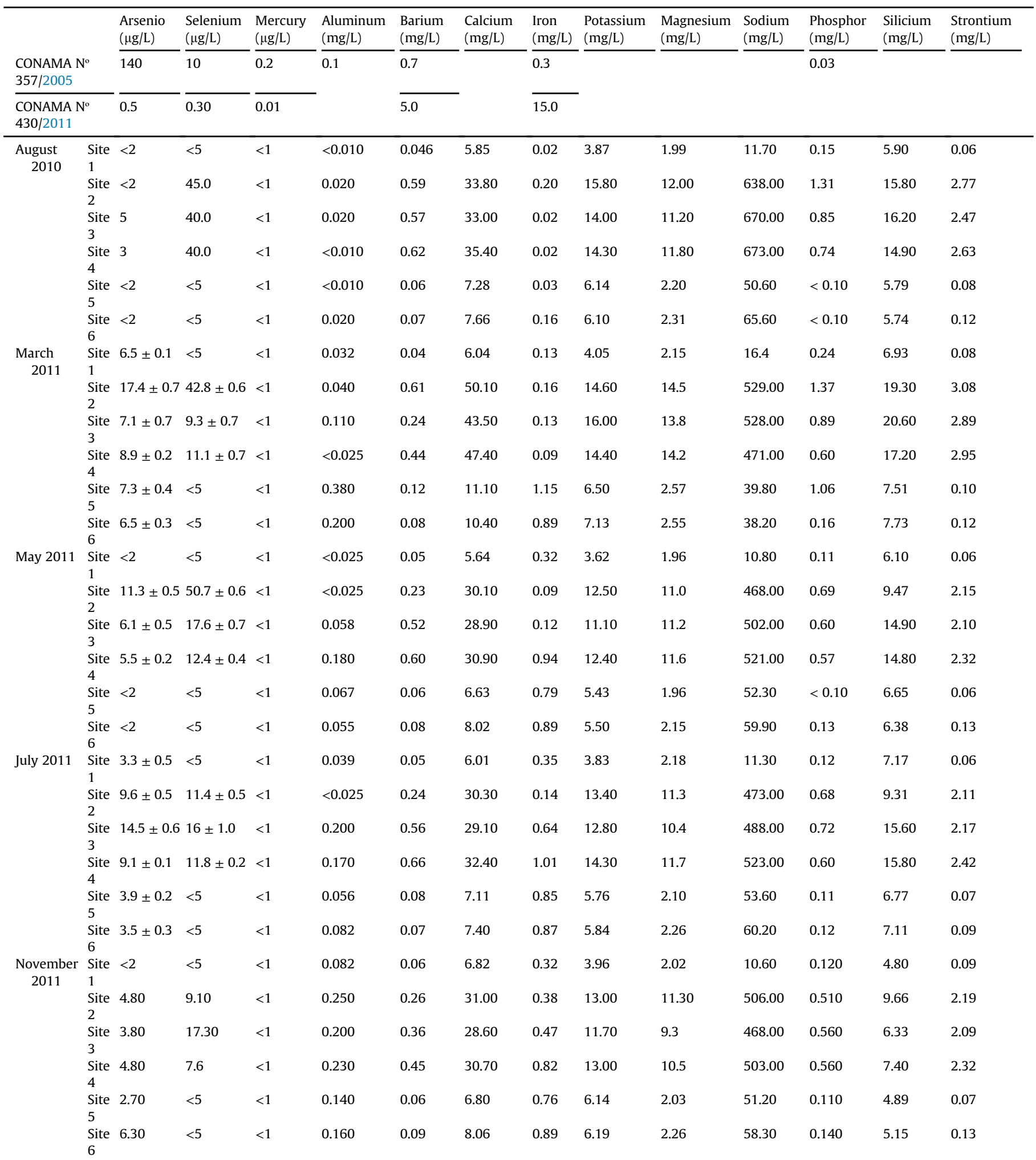

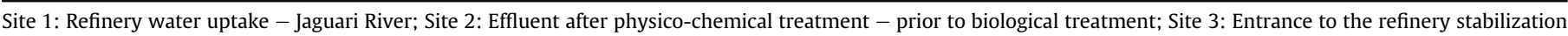

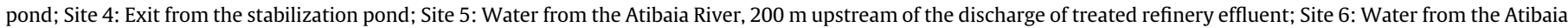
River - about $800 \mathrm{~m}$ downstream of the discharge of treated refinery effluent.

Hoshina and Marin-Morales (2009) evaluated the effluent from the same petroleum refinery during various stages of treatment, as well as the influence of the final effluent in the waters of the Atibaia River. The authors observed that the refinery effluents had in their 
composition substances with cytotoxic and genotoxic potential. Therefore, the water downstream of the refinery effluent discharge (Atibaia River) presented an increase in cell death, CA and MN frequencies that the authors suggest could result from the synergism between effluent contaminants and other contaminants already present in the river due to other releases upstream of the refinery. Barros et al. (2006) evaluated the toxicity of the effluent from this same refinery, for the same sampling sites, by testing with Dugesia trigrina (planarians). The authors observed a toxic effect only for the effluent after the physico-chemical treatment (before biological treatments and the stabilization pond), since this specific sample prevented planarian regeneration.

Studies conducted by Mazzeo et al. (2010) concerning the hydrocarbon degrading potential by a pool of heterotrophic bacteria, revealed that Pseudomona putida and Gram negative Bacillus were the main degrading of hydrocarbon. According to studies by Becker (2015), representatives of several bacteria families, among them species from Pseudomoneaceas and Bacillaceae families, were found in the Paulinia refinery effluent, in the sites related to Sites 2 and 4 from the present study. Thus, it is possible to suggest that the biological treatment and the stabilization pond can be associated with the subsequent decontamination of the refinery effluent after these treatment processes, as observed in the present study. Decontamination should be related to both the presence of these bacteria families and also with the presence of other groups of bacteria that certainly have acted synergistically in the degradation of pollutants present in the waste water of the refinery.

The Atibaia River replevied the petrochemical industry waste from Paulinia-SP. After analysis, the sample collected from Site 6 showed no significant levels of genotoxicity when compared to the negative control. Considering this result, we can infer that the refinery activities did not interfere with the quality of the Atibaia River for the collections performed in this study.

The assessment of the genotoxicity of rivers impacted by industrial activities is important, to verify the reactions of living organisms to pollution (Al-sabti and Metcalfe, 1995). Nunes et al. (2011) evaluated the toxicity and genotoxicity of water samples collected along the Sinos River - RS, which is a water resource influenced by several industrial activities (leather, petrochemical, metallurgy, etc) by assays with A. cepa and V79 cell line (Chinese hamster lung cells). The authors observed a significant increase in the frequency of DNA damage for all samples collected during the spring through the comet assay. A. cepa tests indicated that most of the samples presented cytotoxic but not genotoxic action, since all samples did not induce significant levels of MN. Finally, the authors concluded that the tests with V79 cells and $A$. cepa were effective in detecting toxicity and genotoxicity of complex mixtures. A study performed by Leme and Marin-Morales (2008) assessed four distinct parts of the Guaecá River after the impact caused by a petrochemical industry pipeline leakage, using A. cepa meristematic and $\mathrm{F} 1$ cells. The chemical analyses confirmed the presence of total petroleum hydrocarbons (TPH) and polycyclic aromatic hydrocarbons (PAHs) in this river water, and these contaminants induced genotoxic and mutagenic effects on the exposed test organism. In the F1 cell analyses, it was observed that fixed genotoxic changes to the meristematic cells were transferred to F1 cells, resulting in increased $\mathrm{MN}$ (mutagenic) frequency in those cells.

The results obtained in our analysis with meristematic and F1 cells of $A$. cepa showed that the damage to the meristematic cells was not transferred to the daughter cells because there was no significant level of MN in F1 cell damage. Thus, it is possible to conclude that the contaminants present in the water and effluent do not present mutagenic potential. Our results reinforce those described by Rodrigues et al. (2010) concerning genotoxicity of effluent from other oil refineries evaluated by in vivo tests (MN in
A. cepa) and in vitro assay (comet assay in HTC cells). The results obtained by these authors indicate that PAHs present in the samples studied did not induce the formation of MN in F1 cells of A. cepa, but induced DNA damage in HTC cells, suggesting genotoxic but not mutagenic action.

Among mammals, rodent cells (CHO-K1, V79, and lymphocytes) and human cells (lymphocytes, hepatocytes, and HepG2) are indicated for the analysis of DNA damage resulting from chemical agent action, and for this reason are widely used in evaluations of environmental contamination. CHO-K1 (Chinese Hamster Ovary) cells are widely used for analysis of the induction of DNA damage and additionally offer the advantages of ease of growth in culture and relatively short cell cycle (10-14 h) (Preston et al., 1987).

Our analysis performed with $\mathrm{MN}$ test on $\mathrm{CHO}-\mathrm{K} 1$ cells allowed the observation that only the Site 2 , for the three different collections, showed a significant increase in MN frequency, indicating the presence of substances that cause genomic instability.

Morgan et al. (1996) argue that the increased frequency of genetic material changes causes loss of genomic stability, which is an important aspect of mutagenesis and of genetic alterations associated with carcinogenesis. The presence of micronucleated cells is accepted as indication of aneugenic action, when MN formation is related to the loss of entire chromosomes by mitotic spindle malfunction or is indicative of clastogenic action when the broken chromosome fragments lead to the formation of MN (Al-sabti and Metcalfe, 1995; Leme and Marin-Morales, 2008).

Studies conducted by Krishnamurthi et al. (2007) in mammalian cell (CHO-K1) culture revealed a genotoxic potential for sludge generated by a petroleum refinery. The sludge generated by this type of industrial activity may contain toxic compounds, such as PAHs.

Many studies have associated the incidence of nuclear abnormalities (NA) with the MN count performed in the conventional tests (Cavas and Ergene-Gözüraka, 2005). Although the mechanisms that lead to NA formation are not fully known, many studies suggest that these changes are induced in response to exposure of cells to genotoxic agents (Serrano-Garcia and Montero-Montoya, 2001). For Fenech et al. (2003), counting the nuclear buds in binucleated cells enables a better assessment of the genotoxic potential of an agent. Our results showed a significant increase in the nuclear bud frequency for samples from Site 2 collected in May and July, and for samples from Sites 5 and 6 collected in July 2011.

Fenech and Crott (2002) and Fenech et al. (2003) state that nuclear bridges occur when the centromeres of dicentric chromosomes or chromatids are pulled to opposite poles during anaphase, an event that may indicate a clastogenic action of environmental contaminants. It was observed that the sample from Site 2 collected in July 2011 presented a significant increase in the level of nuclear bridges.

In addition, results obtained by $\mathrm{MN}$ tests in $\mathrm{CHO}-\mathrm{K} 1$ confirm the idea that the refinery treatment system was efficient in decreasing the genotoxic potential of the effluent, observed by the absence of damage in samples from Site 4 and 6.

The physical and chemical analyses of water and effluent samples carried out in this study showed that the samples from Site 2 presented several parameters with high levels, such as conductivity, chlorides, ammonia, sulfides, chemical oxygen demand (COD), biochemical oxygen demand (BOD) and dissolved oxygen (DO).

The increase in electrical conductivity of river water is due to the presence of dissolved materials, which may affect the quality of water resources (Marinelli et al., 2000). Furthermore, when dissolved oxygen levels are low, the water quality is impaired because $\mathrm{O}_{2}$ concentration is not sufficient to assist in the process of biodegradation of organic matter (Bellanger et al., 2004). When this happens, it can be a strong indicator of eutrophication due to the 
dumping of untreated or inadequately treated domestic and industrial effluents (Matheus and Tundisi, 1988).

Pathiratne et al. (2015) used the A. cepa test system to evaluate the impacts resulting from the disposal of effluent generated by several industrial activities on the Kelani River, Sri Lanka. The authors observed high levels of iron and aluminum in most effluents and correlated the presence of these metals with a significant decrease in the mitotic index for all tested effluent samples (raw samples). Düsman et al. (2014) assessed the cytotoxicity (mitotic index) of collected water (4 points) in the Quatorze River (Paraná State, Brazil) by assays with meristematic cells of $A$. cepa. The authors noted that there were no changes in the division rate of the cells exposed to water samples from three of the four collection points. Ferreira et al. (2012) studied the waters of the Varginha and Tabatinga streams (Paraná State, Brazil), through IM of $A$. cepa meristematic cells, and found that these waters showed no cytotoxicity, even presenting values of physico-chemical parameters above the acceptable limits established by the CONAMA 357/205 legislation.

The refinery wastewater, after passing through effluent treatment systems (biological treatment with activated sludge and stabilization pond) showed a significant decrease in the levels of almost all physico-chemical parameters, which allowed us to conclude that the effluent discharged into the Atibaia River does not interfere with the quality of its water and that treatment applied by the refinery is shown to be effective for this type of industrial effluent.

\section{Conclusions}

Many studies are being conducted to determine the cytotoxic, genotoxic, and mutagenic potential of oil and its derivatives. This material is present in high concentrations in the environment, causing a possible threat to ecosystems and to human health. Thus, tests with plant and mammalian cell lines are constantly being applied in the assessment of the toxicity of environmental contaminants, results from which have been shown to be highly suitable for this purpose.

Based on the data presented in this work, it is possible to reinforce the importance of performing environmental monitoring of water bodies receiving industrial and urban effluents, because the chemical compounds present in these effluents can contribute to serious environmental impairment, which can affect both the means physical and the biota of these environments. In conclusion, it is possible to prove the efficiency of biological treatment with activated sludge, supplemented by a stabilization pond, in the decontamination of industrial effluents, especially from the petrochemical industries.

\section{Conflict of interest}

The authors declare that they have no conflict of interest.

\section{Acknowledgements}

The authors would like to thank Prof. Dejanira Franceschi de Angelis from UNESP - Rio Claro for the help the development of this work, and to the Human Resources Program from ANP/PETROBRAS, PRH05 at the São Paulo State University (UNESP - Rio Claro) and FAPESP (process number 2010/13993-0) for the financial support.

\section{References}

Aina, R., Palin, L., Citterio, S., 2006. Molecular evidence for benzo[a]pyrene and naphthalene genotoxicity in Trifolium repensL. Chemosphere 65, 666-673.

Almasi, A., Dargahi, A., Amrane, A., Fazlzadeh, M., Mahmoudi, M., Hashemian, A., 2014. Effect of the retention time and the phenol concentration on the stabilization pond efficiency in the treatment of oil refinery wastewater. Fresenius Environ. Bull. 23 (10a).

Al-sabti, K., Metcalfe, C.D., 1995. Fish Micronuclei for Assessing Genotoxicity in Water, vol. 343. Mutation Research, Amsterdam, pp. 121-135.

Ana, G.R., Sridhar, M.K., Emerole, G.O., 2012. Polycyclic aromatic hydrocarbon burden in ambient air in selected Niger Delta communities in Nigeria. J. Air Waste Manag. Assoc. 62, 18-25.

AWWA (American Water Works Association), 1998. Standard Methods for the Examination of Water and Wastewater, twentieth ed. American Public Health Association, American Water Works Association and Water Environment Federation.

Barros, G.S., Angelis, D.F., Furlan, L.T., Corrêa-Júnior, B., 2006. Utilização de planárias da espécie Dugesia (Girardia) tigrina em testes de toxicidade de efluentes de refinaria de petróleo. J. Braz. Soc. Ecotoxicol. 1, 67-70.

Becker, A.C.F., 2015. Identificação taxonômica e análise conexionista de bactérias heterotróficas e fatores abióticos de ambientes lóticos sob influência de efluentes do refino de petróleo. In: Trabalho de Conclusão de Curso apresentado ao Instituto de Biociências da Universidade Estadual Paulista "Júlio de Mesquita Filho" - Câmpus de Rio Claro, para obtenção do grau de Ecóloga.

Bellanger, B., Huon, S., Steinmann, P., Chabaux, F., Velásquez, F., Valles, V., Arn, K., Clauer, N., Mariotti, A., 2004. Oxic-anoxic conditions in the water column of a tropical freshwater reservoir (Peña-Larga dam, NW Venezuela). Appl. Geochem. 19, 1295-1314.

Bianchi, E., Goldoni, A., Trintinaglia, L., Lessing, G., Silva, C.E., Nascimento, C.A. Ziulkoski, A.L., Spilki, F.R., Silva, L.B., 2015b. Evaluation of genotoxicity and cytotoxicity of water samples from the Sinos River Basin, southern Brazil. Braz J. Biol. 75, 68-74.

Bianchi, J., Espindola, E.L.G., Marin-Morales, M.A., 2011. Genotoxicity and mutagenicity of water samples from the Monjolinho River (Brazil) after receiving untreated effluents. Ecotoxicol. Environ. Saf. 74, 826-833.

Bianchi, J., Mantovani, M.S., Marin-Morales, M.A., 2015a. Analysis of the genotoxic potential of low concentrations of Malathion on the Allium cepa cells and rat hepatoma tissue culture. J. Environ. Sci. (China) 36, 102-111.

Brown, K.W., Donelly, K.C., 1984. Mutagenic activity of runoff and leachate water from hazardous waste and land treatment. Environ. Pollut. Ser. A) 35, 229-246.

Cavas, T., Ergene-Gözüraka, S., 2005. Induction of micronuclei and nuclear abnoramities in Oreochromis niloticus following exposure to petroleum refinery and chromium processing plant effluents. Aquat. Toxicol. 74, 264-271.

CETESB (Companhia de Tecnologia e Saneamento Ambiental). Guia de coleta e preservação de amostras de água. Coord. Edmundo Garcia Agudo (et al.), São Paulo, 1987.

Conselho Nacional do Meio Ambiente (CONAMA), 2005. Resolução número 357, de 17 de março de 2005 (Accessed 5 May 2013). www.mma.gov.br/port/conama/ res/res05/res35705.pdf.

Conselho Nacional do Meio Ambiente (CONAMA), 2011. Resolução número 430, de 13 de maio de 2011 (Accessed 5 May 2013). www.mma.gov.br/port/conama/ legiabre.cfm?codlegi $=646$.

Dearfield, K.L., Cimino, M.C., Mccarroll, N.E., Mauer, I., Valcovic, L.R., 2002. Genotoxicity risk assessment: a proposed classification strategy. Mutat. Res. 521, $121-135$.

Düsman, E., Luzza, M., Savegnago, L., Lauxen, D., Vicentini, V.E.P., Tonial, I.B., Sauer, T.P., 2014. Allium cepa L. as a bioindicator to measure cytotoxicity of surface water of the Quatorze River, located in Francisco Beltrão, Paraná. Braz. Environ. Monit. Assess. 186, 1793-1800.

Fenech, M., 2000. The in vitro micronucleus technique. Mutat. Res. 455, 81-95.

Fenech, M., Chang, W.P., Kirsch-Volders, M., Holland, N., Bonassi, S., Zeiger, E., 2003. Humn project: detailed description of the scoring criteria for the cytokinesisblock micronucleus assay using isolated human lymphocyte cultures. Mutat. Res. 534, 65-75.

Fenech, M., Crott, J.W., 2002. Micronuclei, nucleoplasmic bridges and nuclear buds induced in folic acid deficient human lymphocytes-evidence for breakagefusion-bridge cycles in the cytokinesis-block micronucleus assay. Mutat. Res. 504, 131-136

Fernandes, T.C.C., Mazzeo, D.E.C., Marin-Morales, M.A., 2007. Mechanism of micronuclei formation in polyploidizated cells of Allium cepa exposed to trifluralin herbicide. Pestic. Biochem. Physiol. 88, 252-259.

Fernandes, T.C.C., Mazzeo, D.E.C., Marin-Morales, M.A., 2009. Origin of nuclear and chromosomal alterations derived from the action of an aneugenic agent trifluralin herbicide. Ecotoxicol. Environ. Saf. 72, 1680-1686.

Ferreira, C.F., Frueh, A.B., Düsman, E., Heck, M.C., Vicentini, V.E.P., 2012. Avaliação da citotoxicidade das águas dos Ribeirões Varginha (Califórnia-PR) e Tabatinha (Mandaguari-PR), em Allium cepa L. SaBios Rev. Saúde Biol. 7, 46-54.

Fiskesjö, G., 1985. The Allium test as a standard in environmental monitoring. Hereditas 102, 99-112.

Grant, W.F., 1982. Chromossome aberration assays in Allium. A report of the U.S. environmental protection agency. Gene-Tox program. Mutat. Res. 99, 273-291.

Guencheva, T.N., Henriquers, J.A.P., 2003. Metabolismo de xenobióticos. Citocromo P450. In: Da Silva, J., Erdtman, B., Pegas Fenriques, J.A. (Eds.), Genética Toxicológica, Brasil, pp. 225-243.

Harvey, R.G., 1997. Polycyclic Aromatic Hydrocarbons. Wiley-VCH, New York, p. 682.

Hoshina, M.M., Angelis, D.F., Marin-Morales, M.A., 2008. Induction of micronucleus and nuclear alterations in fish (Oreochromis niloticus) by a petroleum refinery 
effluent. Mutat. Res. 656, 44-48.

Hoshina, M.M. Marin-Morales, M.A., 2009. Micronucleus and chromosome aberrations induced in onion (Allium сера) by a petroleum refinery effluent and by river water that receives this effluent? Ecotoxicol. Environ. Saf. 72, 2090-2095.

Kim, E.H., Jun, Y.R., Jo, H.J., Shim, S.B., Jung, J.H., 2008. Toxicity identification in metal plating effluent: implications in establishing effluent discharge limits using bioassays in Korea. Mar. Pollut. Bull. 57, 637-644.

Kirsch-Volders, M., Sofuni, T., Aardema, M., Albertini, S., Eastmond, D., Fenech, M., Ishidate, J.R., M, Kirchner, S., Lorge, E., Morita, T., Norppa, H., Surralles, J., Vanhauwaert, A., Wakata, A., 2003. Report from the in vitro micronucleus assay working group. Mutat. Res. 540, 153-163.

Krishnamurthi, K., Devi, S.S., Chakrabarti, T., 2007. The genotoxicity of priority polycyclic aromatic hydrocarbons (PAHs) containing sludge samples. Métodos Toxicol. Mech. 17, 1-12.

Lagerqvista, A., Håkanssona, D., Lundinb, C., Prochazkab, G., Dreijc, K., Segerbäckb, D., Jernströmc, B., Törnqvistd, M., Franke, H., Seidele, A., Erixona, K., Jenssena, D., 2011. DNA repair and replication influence the number of mutations per adduct of polycyclic aromatic hydrocarbons in mammalian cells. DNA Repair 10, 877-886.

Leme, D.M., Marin-Morales, M.A., 2008. Chromosome aberration and micronucleus frequencies in Allium cepa cells exposed to petroleum polluted water - a case study. Mutat. Res. 650, 80-86.

Lemos, C.T., Rödel, P.M., Terra, N.R., Oliveira, N.C.D., Erdtmann, B., 2007. River water genotoxicity evaluation using the micronucleus assay in fish erythrocytes. Ecotox. Environ. Saf. 66, 391-401.

Linsak, D.T., Linsak, Z., Besic, D., Vojcić, N., Telezar, M., Coklo, M., Susnić, S., Mićović, V., 2011. Polycyclic aromatic hydrocarbons and heavy metals in Kostrena coastal area. Coll. Antropol. 35, 1193-1196.

Magdaleno, A., Juárez, A.B., Dragani, V., Saenz, M.E., Paz, M., Moretton, J., 2014. Ecotoxicological and genotoxic evaluation of Buenos Aires city (Argentina) hospital wastewater. J. Toxicol. 248461, 2014.

Manzano, B.C., Roberto, M.M., Hoshina, M.M., Menegário, A.A., Marin-Morales, M.A., 2015. Evaluation of the genotoxicity of waters impacted by domestic and industrial effluents of a highly industrialized region of São Paulo State, Brazil, by the comet assay in HTC cells. Environ. Sci. Pollut. Res. Int. 22 (2), 1399-1407.

Marinelli, C.E., Moretto, E.M., Brucha, G., De Lucca, J.V., Limnologia, Espíndola, E.L.G., Silva, J.S.V., Marinelli, C.E., Abdon, M.M. (Eds.), 2000. A Bacia Hidrográfica do Rio do Monjolinho, Rima, São Carlos, pp. 133-149.

Matheus, C.E., Tundisi, J.G., 1988. Estudo físico-químico e ecológico dos rios da bacia hidrográfica do Ribeirão e Represa do Lobo (Broa). In: Tundisi, J.G. (Ed.), Limnologia e Manejo de Represas. Série Monografias em Limnologia. Universidade de São Paulo, São Carlos, pp. 419-471.

Matsumoto, S.T., Mantovani, M.S., Marin-Morales, M.A., 2005. Evaluation of the genotoxic potential due to the action of an effluent contaminated with chromium, by the comet assy in CHO-K1 cultures. Caryologia 58, 40-46.

Mazzeo, D.E.C., Levy, C.E., De Angelis, D.F., Marin-Morales, M.A., 2010. Btex biodegradation by bacteria from effluents of petroleum refinery. Sci. Total Environ. 408, 4334-4340.

Mazzeo, D.E.C., Fernandes, T.C.C., Marin-Morales, M.A., 2011. Danos celulares no Allium cepa sistema de teste, causadas por mistura BTEX prévias e após processo de biodegradação. Chemosphere 85, 13-18.

Morgan, W.F., Day, J.P., Kaplan, M.I., McGhee, E.M., Limoli, C.L., 1996. Genomic Instab. Induc. by Ioniz. Radiat. 146, 247-258.

Nirogi, R., Goyal, V.K., Jana, S., Pandey, S.K., Gothi, A., 2014. Mutagenicity and clastogenicity evaluation of metaphenoxy benzyl chloride by ames and micronucleus assays. Drug Chem. Toxicol. 11, 1-6.

Nogueira, A.A., 2013. Biofiltracão e oxidacão avancada para tratamento terciario e reuso de efluentes de refinaria de petroleo. Dissertacão (Mestrado em Programa de pos-graduacão em Engenharia Quimica) - COPPE. Universidade Federal do Rio de Janeiro, Rio de Janeiro, p. 149.

Nunes, E.A., Lemos, C.T., Gavronski, L., Moreira, T.N., Oliveira, N.C.D., Silva, J., 2011.
Genotoxic assessment on river water using different biological systems. Chemosphere 84, 47-53.

Nwanyanwu, C.E., Abu, G.O., 2010. In vitro effects of petroleum refinery wastewater on dehydrogenase activity in marine bacterial strains. Ambi-Agua 5 (2), 21-29.

Ohe, T., Watanabe, T., Wakabayashi, K., 2004. Mutagens in surface waters: a review. Mutat. Reseach 567, 109-149.

Palmieri, M.J., Andrade-Vieira, L.F., Campos, J.M., Dos Santos, G.L., Davide, L.C., 2016. Cytotoxicity of Spent Pot Liner on Allium cepa root tip cells: a comparative analysis in meristematic cell type on toxicity bioassays. Ecotoxicol. Environ. Saf. 9 (133), 442-447.

Pathiratne, A., Hemachandra, C.K., Silva, N.D., 2015. Efficacy of Allium cepa test system for screening cytotoxicity and genotoxicity of industrial effluents originated from different industrial activities. Environ. Monit. Assess. 187, 730.

Preston, R.J., San Sebastian, J.R., Mcfee, 1987. A.FThe in vitro human lymphocyte assay for assessing the clastogenicity of chemical agents. Mutat. Res. 189 175-183.

Rabello-Gay, M., Rodrigues, M.A.R., 1991. Mutagênese, teratogênese e carcinogênese: Métodos e critérios de avaliação. Ribeirão Preto: Sociedade Brasileira de Genética.

Reifferscheid, G., Ziemann, C., Fieblinger, D., Dill, F., Gminski, R., Grummte, H., Hafner, C., Hollert, H., Kunz, S., Rodrigo, G., Stopper, H., Selke, D., 2008. Measurement of genotoxicity in wastewater samples with the in vitro micronucleus test-results of a round-robin study in the context of standardisation according to ISO. Mutat. Res. 649, 15-27.

Rhind, S.M., 2009. Anthropogenic pollutants: a threat to ecosystem sustainability? Philos. Trans. R. Soc. Lond B Biol. Sci. 364, 3391-3401.

Rodrigues, F.P., Angeli, J.P., Mantovani, M.S., Guedes, C.L., Jordão, B.Q., 2010. Genotoxic evaluation of an industrial effluent from an oil refinery using plant and animal bioassays. Genet. Mol. Biol. 33, 169-175.

Rogero, S.O., Lugão, A.B., Ikeda, T.I., Cruz, A.S., 2003. Teste in vitro de citotoxicidade: estudo comparativo entre duas metodologias. Mater. Res. 6, 317-320.

Russel, P.J., 2002. Chromosomal mutation. In: Cummings, B. (Ed.), Genetics. Pearson Education Inc., San Francisco, pp. 595-621.

Saien, J., Shahrezaei, F., 2012. Organic pollutants removal from petroleum refinery wastewater with nanotitania photocatalyst and UV light emission. Int. J. Photoenergy 2012. Article ID 703074.

Santaella, S.T., Silva, F.C.G.J., Gadelha, D.A.C. Costa, K.O., Aguiar, R., Arthaud, I.D.B. Leitão, R.C., jan/mar 2009. Tratamento de efluentes de refinaria de petroleo em reatores com Aspergillus Niger. Eng. Sanitaria Ambient. Fortaleza 14 (1) 139-148.

Serrano-Garcia, L., Montero-Montoya, R., 2001. Micronuclei and chromatine buds are related genotoxic events. Environ. Mol. Mutagen. 38, 38-45.

Souza, D.S., Ramos, A.P., Nunes, F.F., Moresco, V., Taniguchi, S., Leal, D.A., Sasaki, S.T., Bícego, M.C., Montone, R.C., Durigan, M., Teixeira, A.L., Pilotto, M.R., Delfino, N. Franco, R.M., Melo, C.M., Bainy, A.C., Barardi, C.R., 2012. Evaluation of tropical water sources and mollusks in southern Brazil using microbiological biochemical, and chemical parameters. Ecotoxicol. Environ. Saf. 2, 153-161.

Sun, L., Zang, S., 2012. History of fuel consumption inferred from polycyclic aromatic hydrocarbons in sediments from the south lianhuan lake, northeast China. Bull. Environ. Contam. Toxicol. 88, 1027-1032.

Teixeira, C.P.A.B., Jardim, W.F., 2004. Processos oxidativos avancados: conceitos teoricos. Laboratorio de Quimica Ambiental, Instituto de Quimica, Universidade Estadual de Campinas. Cad. tematico 3, 83.

Tian, D., Zheng, W., He, G., Zheng, Y., Andersen, M.E., Tan, H., Qu, W., 2015. Predicting cytotoxicity of complex mixtures in high cancer incidence regions of the Huai River Basin based on GC-MS spectrum with partial least squares regression. Environ. Res. 137, 391-397.

Van der Oost, R., Beyer, J., Vermeulen, N.P.E., 2003. Fish bioaccumulation and biomarkers in environmental risk assessment: a review. Environ. Toxicol. Pharmacol. 13, 57-149. 